\title{
INTERNALISASI DAN AKTUALISASI NILAI-NILAI KARAKTER PADA SISWA SMP DALAM PERSPEKTIF FENOMENOLOGIS
}

(Studi Kasus Di SMP 2 Bantul)

\author{
${ }^{1)}$ Titik Sunarti Widyaningsih, ${ }^{2}$ Zamroni, ${ }^{3)}$ Darmiyati Zuchdi \\ ${ }^{1)}$ SMP Negeri 1 Banguntapan, ${ }^{2,3}$ Universitas Negeri Yogyakarta \\ ${ }^{1)}$ titik_sw@yahoo.com, ${ }^{2)}$ zamronihardjowirono@yahoo.com,
}

\begin{abstract}
Abstrak
Penelitian ini bertujuan untuk: (1) mengidentifikasi nilai-nilai karakter yang difasilitasi sekolah untuk diinternalisasi dalam diri siswa, (2) mengetahui proses internalisasi nilai karakter pada diri siswa, dan (3) mengidentifikasi nilai-nilai karakter yang telah diaktualisasi siswa dalam perilaku sehari-hari. Paradigma penelitian ini adalah kualitatif dengan menggunakan pendekatan fenomenologis. Subjek penelitian adalah kepala sekolah, guru, dan siswa di SMP Negeri 2 Bantul. Penentuan subjek penelitian dilakukan dengan teknik purposive dengan cara memilih sejumlah informan yang disesuaikan dengan tujuan penelitian. Data dikumpulkan dengan menggunakan pengamatan nonpartisipan, wawancara mendalam dan dokumentasi. Teknik analisis data mengacu pada langkah-langkah analisis data yang dikemukakan oleh Egan (2009, p.281). Hasil penelitian menunjukkan bahwa nilai-nilai karakter yang difasilitasi oleh sekolah untuk diinternalisasi dalam diri siswa SMP 2 Bantul adalah nilai religius, kejujuran, tanggung jawab, kesopanan, saling menghargai, peduli pada lingkungan dan cinta tanah air. Nilai-nilai karakter yang telah diaktualisasi dalam perilaku sehari-hari siswa di SMP 2 Bantul adalah nilai religius, kejujuran, tanggung jawab, kesopanan, saling menghargai, dan peduli pada lingkungan
\end{abstract}

Kata kunci: internalisasi, aktualisasi, nilai-nilai karakter

\section{THE INTERNALIZATION AND ACTUALIZATION OF CHARACTER VALUES IN THE STUDENTS OF JUNIOR HIGH SCHOOLS IN PHENOMENOLOGICAL PERSPECTIVE}

(A Case Study in SMP 2 Bantul)

\author{
${ }^{1)}$ Titik Sunarti Widyaningsih, ${ }^{2)}$ Zamroni, ${ }^{3)}$ Darmiyati Zuchdi \\ ${ }^{1)}$ SMP Negeri 1 Banguntapan, ${ }^{2,3)}$ Universitas Negeri Yogyakarta \\ ${ }^{1)}$ titik_sw@yahoo.com, ${ }^{2)}$ zamronihardjowirono@yahoo.com,
}

\begin{abstract}
This study aims to: (1) identify the values of character facilitated by the school to be internalized in the students, (2) determine the process of internalization of the character in the students, and (3) identify the character values that have been actualized in the students' daily behavior. This is a qualitative research using a phenomenological approach. The subjects were the principal, teachers, and students of SMP Negeri 2 Bantul. The determination of the subjects was done by using the purposive technique by selecting a number of respondents who are tailored to the purpose of this research. The data were collected through non-participant observation, in-depth interviews and documentation. The technique of data analysis refers to the steps of data analysis proposed by Egan T Marshall (2009:281). The results show that the values of character facilitated by the school for students to be internalized in the students include religious values, honesty, responsibility, courtesy, respect, care for the environment, and love of homeland. The character values that have been actualized in the daily behavior of the students of SMP 2 Bantul are religious values, honesty, responsibility, courtesy, respect, and care for the environment.
\end{abstract}

Keywords: internalization, actualization, character values 


\section{PENDAHULUAN}

Undang-Undang Nomor 20 Tahun 2003 tentang Sistem Pendidikan Nasional menyatakan bahwa "pendidikan berfungsi mengembangkan kemampuan dan membentuk watak serta peradaban bangsa yang bermartabat dalam rangka mencerdaskan kehidupan bangsa". Berdasarkan definisi tersebut dapat dimaknai bahwa fungsi pendidikan tidak semata-mata mengembangkan kemampuan, namun juga dimaksudkan untuk membentuk watak dan peradaban suatu bangsa yang bermartabat. Bangsa yang bermartabat dicirikan dengan bangsa yang memiliki akhlak mulia dan cerdas sebagaimana yang menjadi tujuan pendidikan nasional.

Namun demikian, dalam realita sosialnya masih terjadi ketimpangan antara tujuan membangun kecerdasan dan tujuan membangun karakter. Peran sekolah selama ini hanya tertuju pada domain intelektual, sedangkan domain karakter belum dikembangkan secara optimal. Sebagai contohnya pendidikan karakter yang diakomodasikan secara terbatas dengan mengintegrasikan pendidikan karakter dalam Pendidikan Agama dan pendidikan Kewarganegaraan (PKn) sedangkan mata pelajaran lainnya tidak mengintegrasikan pendidikan karakter.

Demikian halnya pelaksanaan pendidikan karakter yang dilakukan oleh guru Agama dan PKn cenderung bersifat transfer materi dan tranfer nilai sehingga hanya menyentuh pada ranah permukaan. Sebagai contohnya metode penyampaian yang digunakakan hanya melalui ceramah, dan metode penilaian dilakukan secara kognitif melalui penilaian soal pilihan ganda (multiple choice), isian terstruktur, dan uraian tidak menekankan pada proses bagaimana nilai-nilai karakter dapat ter-internalisasi pada diri siswa.

Internalisasi nilai tidak berlangsung secara optimal berdampak pada tidak teraktualisasinya nilai-nilai karakter dalam perilaku peserta didik. Berdasarkan data kepolisian di Kabupaten Bantul, selama kurun waktu 2009-2010 terdapat 45 siswa yang terlibat kasus tindak pidana kriminal berupa pencurian, melarikan gadis di bawah umur, dan penganiayaan. Disamping itu juga ditemukan kasus pelajar pengguna narkoba. Pada tahun 2009Mei 2010 ditemukan 9 kasus pengguna narkoba yang dilakukan oleh pelajar.
Disamping itu, berdasarkan hasil pengamatan dan wawancara dengan guru Bimbingan Konseling di beberapa SMP Kabupaten Bantul, penyebab pelanggaran yang dilakukan oleh siswa menunjukkan tidak teraktualisasinya nilai-nilai karakter. Hal ini ditunjukkan dengan kasus penyimpangan seperti ketidakjujuran, pelanggaran kedisiplinan, sikap kurang hormat kepada guru, kurangnya tanggung jawab siswa terhadap tugas-tugas yang diberikan guru, kurangnya kepedulian siswa terhadap berbagai masalah baik di lingkungan sekolah maupun masyarakat, pergaulan bebas, dan kurangnya nilai kebangsaan menjadi suatu fenomena nyata yang ditemukan di sekolah-sekolah tersebut.

Hasil penelitian Winarno (2009, p.130) tentang pengembangan model pembelajaran internalisasi nilai-nilai kewirausahaan pada Sekolah Menengah Kejuruan di Kota Malang menyimpulkan bahwa model internalisasi nilai yang relevan diterapkan pada pembentukan sikap/nilai pada dasarnya mencakup tiga tahap, yaitu: 1) tahap transformasi nilai, dimana dalam tahap ini pendidik sekedar menginformasikan nilai-nilai yang baik dan yang kurang baik kepada siswa yang semata-mata komunikasi searah, 2) transaksi nilai yakni suatu tahap pendidikan nilai dengan jalan melakukan komunikasi dua arah, atau interaksi antara peserta didik dengan pendidik yang bersifat interaksi timbal balik secara aktif. Dalam tahap ini pendidik tidak hanya memberikan informasi tentang nilai-nilai tetapi juga terlibat dalam proses menerima dan melaksanakan nilai-nilai itu, dan (3) tahap internalisasi, pada tahap ini jauh lebih dalam yang juga melibatkan tidak hanya aspek fisik, tetapi telah menyangkut sikap mental kepribadian baik bagi pendidik maupun peserta didiknya.

Berdasarkan hasil penelitian tersebut maka sangat urgen dilakukan penelitian tentang internalisasi dan aktualisasi nilai-nilai karakter pada siswa SMP dalam perspektif fenomenologis dengan melihat sudut pandang dari kepala sekolah, guru dan siswa sebagai pelaku dalam proses internalisasi dan aktualisasi nilai-nilai karakter.

Berdasarkan latar belakang tersebut, masalah penelitian ini dapat dirumuskan sebagai berikut: (1) nilai-nilai karakter yang difasilitasi sekolah untuk diinternalisasi dalam diri siswa di SMP 2 Bantul; (2) proses internalisasi nilai-nilai karakter pada diri siswa di 
SMP 2 Bantul; dan (3) nilai-nilai karakter yang telah diaktualisasi dalam perilaku siswa sehari-hari di SMP 2 Bantul.

Penelitian ini bertujuan untuk: (1) mengidentifikasi nilai-nilai karakter yang difasilitasi sekolah untuk diinternalisasi dalam diri siswa, (2) mengetahui proses internalisasi nilai karakter pada diri siswa, dan (3) mengidentifikasi nilai-nilai karakter yang telah diaktualisasikan siswa dalam perilaku seharihari.

Ditinjau secara teoretis, manfaat yang diharapkan dapat diperoleh dalam penelitian ini adalah: (1) sebagai bahan penelitian awal tentang internalisasi dan aktualisasi nilai-nilai karakter pada siswa SMP, (2) sebagai informasi tentang metode pendidikan karakter di SMP Kabupaten Bantul, dan (3) sebagai bahan referensi bagi sekolah-sekolah dalam melaksanakan internalisasi dan aktualisasi nilainilai karakter. Apabila ditinjau dari segi kebijakan, penelitian ini diharapkan memberikan manfaat sebagai berikut: (1) dapat digunakan sebagai bahan pertimbangan untuk membuat kebijakan dalam rangka pelaksanaan pendidikan karakter di sekolah, dan apat digunakan sebagai bahan dalam menyusun kebijakan guna pengembangan sumber daya manusia Indonesia yang berkualitas baik fisik maupun non fisik.

Secara praktis, manfaat yang diperoleh dari penelitian ini adalah: (1) dapat digunakan sebagai bahan masukan dan pertimbangan bagi SMP di kabupaten Bantul guna melakukan evaluasi dan refleksi terhadap pendidikan karakter yang telah dilakukan, (2) dapat digunakan sebagai pedoman kepala sekolah dalam mengembangkan pendidikan karakter di sekolah, dan (3) dapat digunakan sebagai bahan pertimbangan dalam pemecahaan masalah pendidikan yang berkaitan dengan karakter

Battistich sebagaimana dikutip oleh Suwito, et. al. (2008, p.27) mengemukakan bahwa karakter (character) mengacu pada serangkaian sikap (attitudes), perilaku (behaviors), motivasi (motivation), dan keterampilan (skills). Karakter meliputi sikap seperti keinginan untuk melakukan hal yang terbaik, kapasitas intelektual seperti berpikir kritis dan alasan moral, perilaku seperti jujur dan bertanggung jawab, mempertahankan prinsipprinsip moral dalam situasi penuh ketidakadilan, kecakapan interpersonal dan antar- personal yang memungkinkan seseorang berinteraksi secara efektif dalam berbagai keadaan, dan komitmen untuk berkontribusi bagi komunitas dan masyarakatnya. Karakter adalah realisasi perkembangan positif sebagai individu (intelektual, sosial, emosional, dan etika). Individu yang berkarakter baik adalah seseorang yang berusaha melakukan hal terbaik. Hal terbaik memiliki makna sikap, perilaku, motivasi dan keterampilan yang mengacu pada nilai-nilai karakter bangsa.

Dalam kaitannya dengan nilai-nilai karakter, Kemendiknas (2010, p.13) mengidentifikasikan butir-butir nilai yang dikelompokkan menjadi lima nilai utama, yaitu: (1) nilai karakter dalam hubungannya dengan Tuhan, adalah nilai religius, yaitu pikiran, perkataan, tindakan yang sesuai dengan nilainilai Ketuhanan dan ajaran agamannya; (2) nilai karakter dalam hubungannya dengan diri sendiri, meliputi: (a) nilai jujur, (b) bertanggung jawab, (c) bergaya hidup sehat, (d) disiplin, (e) kerja keras, (f) percaya diri, (g) berjiwa wirausaha, (h) berpikir logis, kritis, kreatif, dan inovatif, (i) mandiri, (j) ingin tahu, dan (k) cinta ilmu; (3) nilai karakter dalam hubungannya dengan sesama, meliputi: (1) sadar, (2) patuh, (3) menghargai karya dan prestasi orang lain, (4) santun, dan (5) demokratis; (4) nilai karakter dalam hubungannya dengan lingkungan, yang meliputi nilai peduli sosial dan lingkungan; (5) nilai kebangsaan, meliputi: (1) nasionalis, dan (2) menghargai keberagaman.

Butir-butir nilai tersebut diharapkan diintegrasikan dalam kurikulum pembelajaran di sekolah untuk ditanamkan pada siswa melalui kegiatan pembelajaran, ekstrakurikuler maupun kultur sekolah dengan pendekatan komprehensif sehingga siswa menginternalisasi dan mengaktualisasikan nilai-nilai tersebut dalam perilaku sehari-hari.

Pearson \& Nicholson (2000, p.245) mengemukakan bahwa: "An ideal comprehensive character education program would be a collaborative effort of administrators, teachers, and counselors share two tasks. One is to encourage parental involvement and the other is to serve as role models for students" Pernyataan tersebut mengandung makna bahwa program pendidikan karakter yang komprehensif ideal akan menjadi upaya kolaboratif dari administrator, guru, dan pem- 
bimbing berbagi dua tugas. Salah satunya adalah untuk mendorong keterlibatan orang tua dan yang lainnya adalah untuk melayani sebagai model peran bagi siswa.

Peran pemodelan khususnya adalah jantung dan jiwa dari sebuah program. Karakter yang baik perlu diajarkan dari perspektif "lakukan seperti yang kulakukan" bukan "lakukan seperti saya katakan" Peran seorang administrator/staf adalah untuk fokus terutama pada komunitas sekolah dan lingkungan. Guru memfokuskan upaya mereka pada bagaimana interaksi yang terjadi di kelas. Konselor sekolah berfungsi sebagai konsultan untuk personil sekolah lain karena mereka fokus pada membantu anak-anak mengembangkan karakter yang akan meningkatkan pemahaman mereka tentang diri dan hubungan mereka dengan orang lain.

Sejalan dengan pendapat Pearson \& Nicholson, Kirschenbaum (1995, p.31) mengemukakan "inclucating value and morality, modeling value and morality, facilitating value, and morality, skills for value development, and moral literacy." Berdasarkan pengertian tersebut maka pendekatan komprehensif meliputi inkulkasi (inculcation), keteladanan (modeling), fasilitasi (facilitation), dan pengembangan keterampilan (skill-building)

Inkulkasi atau penanaman nilai memiliki ciri-ciri (1) mengkomunikasikan kepercayaan disertai alasan yang mendasarinya, (2) memperlakukan orang secara adil, (3) menghargai pandangan orang lain, (4) mengemukakan keragu-raguan atau perasaan tidak percaya disertadi dengan alasan, dan dengan rasa hormat, (5) tidak sepenuhnya mengontrol lingkungan untuk meningkatkan kemungkinan penyampaian nilai-nilai yang dikehendaki, dan mencegah kemungkinan penyampaian nilai-nilai yang tidak dikehendaki, (6) menciptakan pengalaman sosial dan emosional mengenai nilai-nilai yang dikehendaki secara tidak ekstrem, (7) membuat aturan, memberikan penghargaan, dan memberikan konsekuensi disertai alasan, (8) tetap membuka komunikasi dengan pihakyang tidak setuju, dan (9) memberikan kebebasan bagi adanya perilaku yanga berbeda-beda, apabila sampai pada tingkat yang tidak dapat diterima, diarahkan untuk memberikan kemungkinan berubah.

Keteladanan nilai merupakan strategi yang biasa digunakan dalam pendidikan karakter. Ada dua syarat yang harus dipenuhi untuk menggunakan strategi ini, yaitu: (1) guru atau orang tua harus berperan sebagai model yang baik bagi murid-muridnya atau anak-anaknya, dan (2) anak-anak harus meneladani orang terkenal yang berakhlak mulia misalnya Nabi Muhammad SAW.

Fasilitasi melatih subjek didik mengatasi berbagai masalah. Bagian terpenting dari fasilitasi adalah pemberian kesempatan kepada subjek didik. Fasilitasi akan memberikan dampak positif pada perkembangan kepribadian anak, karena: (1) kegiatan fasilitasi dapat meningkatkan hubungan antara pendidik dan subjek didik, (2) dapat memperjelas pemahaman karena subjek didik diberi kesempatan untuk menyusun pendapat, mengingat kembali hal-hal yang perlu disimak, dan memperjelas hal-hal yang masih meragukan, (3) fasilitasi menolong subjek didik yang sudah menerima suatu nilai tapi belum mengamalkannya secara konsisten, meningkat dari pemahaman secara intelektual ke komitmen untuk bertindak, (4) fasilitasi menolong subjek didik berpikir lebih jauh tentang nilai yang dipelajari, menemukan wawasan sendiri, belajar dari teman-temannya yang telah menerima nilai-nilai yang diajarkan dan akhirnya menyadari kebaikan halhal yang disampaikan oleh pendidik, (5) kegiatan fasilitasi menyebabkan pendidik lebih memahami pikiran dan perasaan subjek didik, dan (6) fasilitasi memotivasi subjek didik menghubungkan persoalan nilai dengan kehidupan, kepercayaan, dan perasaan mereka sendiri.

Pengembangan keterampilan meliputi keterampilan akademik dan sosial yang diperlukan agar seseorang dapat mengamalkan nilai-nilai yang dianut sehingga berprilaku konstruktif dan bermoral dalam masyarakat, yaitu berpikir kritis, berpikir kreatif, berkomunikasi secara jelas, menyimak, bertindak asertif, dan menemukan resolusi konflik.

Pendidikan karakter dengan pendekatan komprehensif diyakini akan menghasilkan lulusan yang mampu membuat keputusan moral, sekaligus memiliki perilaku yang terpuji berkat pembiasaan terus-menerus dalam proses pendidkan. Metode komprehensif merupakan jabaran dari pendekatan komprehensif. Metode ini merupakan sintesis dari dua metode yang bersifat tradisional, yaitu inkulkasi (kebalikan dari indoktrinasi) dan pem- 
berian teladan, dan dua metode kontemporer, yaitu fasilitasi nilai dan pengembangan keterampilan (soft skills) seperti berpikir kritis, berpikir kreatif, berkomunikasi dengan jelas, dan berbagai keterampilan sosial.

Pendekatan komprehensif tersebut mempermudah terjadinya proses internalisasi dan aktualisasi nilai-nilai karakter pada siswa, karena pendidikan karakter dilakukan secara sinergis antara beberapa komponen sekolah atau stakeholder sekolah dan melibatkan penggunaan beragam metode.

Dalam kaitannya dengan internalisasi, Muhadjir (2000, p.133) mengemukakan bahwa internalisasi adalah interaksi yang memberi pengaruh pada penerimaan atau penolakan nilai (values), lebih memberi pengaruh pada kepribadian, fungsi evaluatif menjadi lebih dominan. Proses internalisasi dilakukan melalui lima jenjang, yaitu: (1) menerima, (2) menanggapi, (3) memberi nilai, (4) mengorganisasi nilai, dan, (5) karakterisasi nilai.

Proses internalisasi benar-benar mencapai tujuannya apabila telah mencapai jenjang yang keempat yaitu mengorganisasikan nilai. Mulai jenjang keempat ini kemudian terjadi proses menuju kepemilikan sistem nilai tertentu. Pada jenjang ini berbagai nilai ditata supaya sinkron dan kohern. Baru pada jenjang kelima proses internalisasi nilai, subyek sudah mulai menyusun hubungan hierarki berbagai nilai dan diorganisasikan sedemikian rupa sehingga menyatu dalam arti sinkron dan kohern. Apabila para pendidik memahami hubungan hierarki serta pengorganisasian berbagai nilai ini, maka proses internalisasi nilai bagi siswa akan terwujud mempribadi dalam diri siswa. Jadi yang diperlukan adalah transinternalisasi program pendidikan, yang maknanya bahwa subyek didik bersama pendidiknya, menghayati program beserta nilainya. Proses lanjut dari penghayatan nilai adalah aktualisasi nilai atau perwujudan nilai dalam perilaku sehari-hari.

Sebuah perilaku terbentuk melalui beberapa tahapan. Tahapan pembentukan perilaku dikemukakan oleh Prochasca \& D'Clemente (Zubaedi, 2012, p.28) yang mengemukakan bahwa dalam perubahan perilaku terdapat lima tahap hingga perilaku tersebut benar-benar terjadi, yaitu:

Tahap satu adalah procontemplation, ialah kondisi awal seseorang yang pada dasarnya manusia tidak ingin mengubah perilaku, tahap dua contemplation, yaitu tahapan mempertimbangkan untuk berubah, tahap tiga preparation, yaitu tahapan membuat sedikit perubahan, tahap empat action, yaitu tahapan dimana seseorang mulai terikat pada perilaku baru, dan tahap lima maintenance, yaitu tahapan mempertahankan perilaku baru.

Tahapan tersebut menunjukkan bahwa untuk mengubah perilaku seseorang maka diperlukan proses sehingga pendidikan karakter yang mengusahakan perubahan perilaku memerlukan waktu yang cukup lama, memerlukan kesabaran, ketelatenan dan kerja sama dari berbagai pihak. Dengan demikian maka nilai-nilai karakter yang telah ditanamkan dalam diri peserta didik akan melembaga dan teraktualisasi sebagai perilaku peserta didik.

\section{METODE PENELITIAN}

Paradigma penelitian ini adalah kualitatif dengan pendekatan fenomenologis. Pendekatan fenomenologis dipilih dengan pertimbangan: (1) judul penelitian berhubungan dengan proses internalisasi dan aktualisasi nilainilai karakter, sehingga memerlukan wawancara mendalam untuk dapat mengungkap tentang bagaimana siswa melakukan internalisasi nilai-nilai karakter dalam dirinya dan nilai-nilai apa saja yang telah berhasil diaktualisasikan dalam perilakunya, dan (2) obyek penelitian adalah persepsi atau pandangan individu tentang nilai-nilai karakter yang diinternalisasikan dan cara melakukan internalisasi nilai-nilai karakter tersebut.

Penelitian ini dilaksanakan di SMP Negeri 2 Bantul yang berlokasi di pusat kota Kabupaten Bantul. Pemilihan SMP 2 Bantul sebagai lokasi penelitian karena SMP Negeri 2 Bantul memiliki beberapa keunikan, antara lain: SMP 2 Bantul merupakan sekolah negeri yang dijadikan sebagai sekolah sekolah Model Pendidikan Agama Islam, dan Kepala sekolah beragama Katholik. Penelitian ini dilaksanakan pada bulan Juli 2011 sampai dengan bulan April 2012

Subjek penelitian adalah kepala sekolah, guru, dan siswa di SMP Negeri 2 Bantul. Penentuan subjek penelitian dilakukan dengan purposive sampling. Teknik purposive sampling dilakukan dengan cara memilih sejumlah responden yang disesuaikan dengan tujuan penelitian. Dalam studi fenomenologi individu yang akan dijadikan informan adalah 
mereka yang dapat memberikan penjelasan dengan baik. Informan dalam penelitian ini adalah kepala sekolah, guru senior, dan siswa.

Prosedur penelitian ini mengacu pada tahapan penelitian menggunakan Grounded Theory dimana Grounded Theory digambarkan sebagai penemuan teori dari data. Grounded Theory merupakan proses penelitian sebagai penemuan teori melalui penelitian sosial. Strauss \& Corbin mendefinisikan Grounded Theory sebagai berikut:

"A grounded theory is one that is inductively derived from the study of the phenomenon it represents. That is, it is discovered, developed and provisionally verified through systematic data collection and analysis of data pertaining to that phenomenon. Therefore, data collection, analysis and theory stand in recip- rocal relationship to one another (Egan, 2002, p.277)

Pernyataan di atas mengandung makna bahwa grounded theory adalah teori yang diperoleh dari hasil pemikiran induktif dalam suatu penelitian tentang fenomena yang ada. Grounded theory ini ditemukan, dikembangkan dan dibuktikan melalui pengumpulan data secara sistematis dan analisis data yang terkait dengan fenomena tersebut. Oleh karena itu kumpulan data, analisis dan teori saling mempengaruhi satu sama lain.

Adapun prosedur penelitian ini menggunakan lima fase dalam membangun teori. Kelima tahap meliputi: (1) pengembangan konseptual, (2)operasionalisasi, (3) aplikasi, (4) konfirmasi atau diskonfirmasi, dan (5) perbaikan terus-menerus dan pengembangan. Adapun kelima tahap tersebut digambarkan seperti Gambar 1.

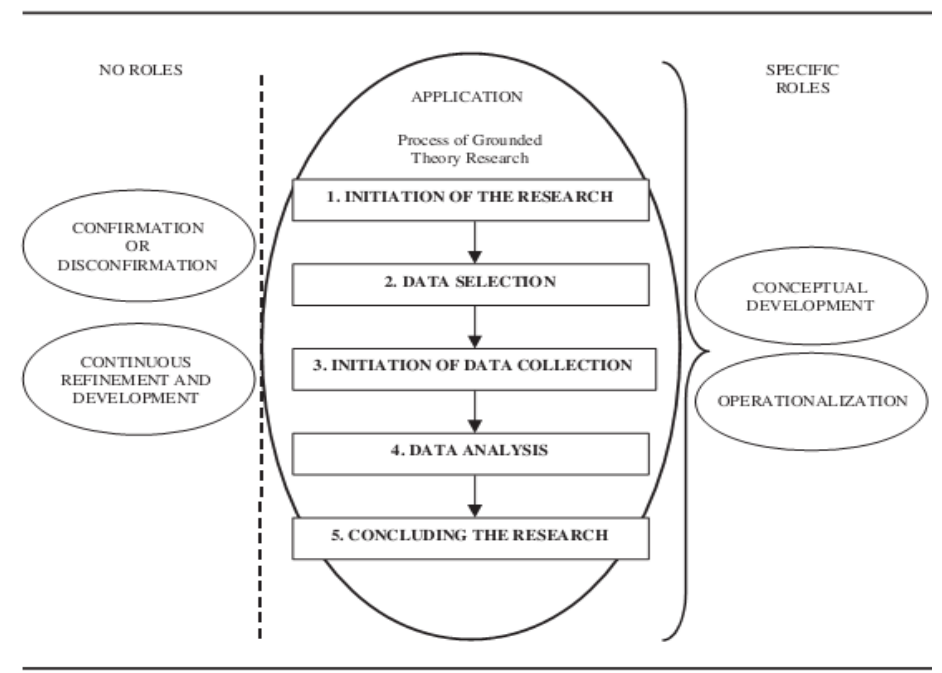

Gambar 1. The Role of Grounded Theory Research in Context of the General Method of Theory Building Research in Applied Disciplines (Egan, 2009, p.288)

Berdasarkan Gambar 1, untuk membangun teori diperlukan proses penelitian Grounded Theory. Pada Gambar 1 ditunjukkan oleh tahapan aplikasi. Setelah melalui tahapan proses penelitian tersebut, kemudian dilanjutkan dengan tahapan pengembangan konseptual atau konseptualisasi yaitu dengan cara membuat konsep berdasarkan data yang telah ditemukan. Tahapan berikutnya adalah operasionalisasi atau pengembangan hipotesis. Hipotesis kemudian diuji dengan tahapan penelitian Grounded Theory seperti penelitian sebelumnya. Melalui proses pengujian hipotesis akan menghasilkan tahapan diterima atau tidak diterima, apabila diterima maka akan dibangun teori berdasarkan temuan yang telah diuji hipotesisnya, namun apabila belum diterima maka dilakukan perbaikan terus menerus dan pengembangan.

Untuk memperoleh data dalam penitian ini dilakukan dengan teknik: pengamatan non partisipan, wawancara mendalam, dan dokumentasi. Pengamatan nonpartisipan artinya peneliti tidak berlaku sebagai kepala sekolah, guru, maupun siswa, namun peneliti hanya mengikuti aktivitas yang dilakukan di sekolah lokasi penelitian. Pengamatan non partisipan dilakukan dengan cara peneliti berada di 
lokasi penelitian untuk melakukan pengamatan terhadap aktivitas aktor yang ada di sekolah yang diamati. Pengamatan dilaksanakan terhadap kultur sekolah, manajemen sekolah, ekstra kurikuler, pembelajaran, aktivitas siswa di sekolah. Wawancara mendalam dilakukan dengan kepala sekolah, guru, dan siswa. Wawancara dilakukan sampai dapat ditemukan sejumlah fenomena yang diperlukan. Metode dokumentasi dilakukan dengan cara menyelidiki benda-benda tertulis seperti visi misi, administrasi pembelajaran guru, dan program sekolah.

Teknik analisis data mengacu pada langkah-langkah analisis data yang dikemukakan oleh Egan (2009, p.281) sebagai berikut: (1) pengkodean data awal, berupa kegiatan penamaan, membandingkan, dan memoing atau pencatatan untuk elaborasi, (2) aplikasi berkelanjutan dari pengkodean apabila terjadi perubahan tempat atau responden, (3) membandingkan dan merevisi kode, (4) memeriksa kategori yang berkembang (5) membentuk kategori, (6) menerapkan dan memodifikasi data set kategori dan sifat-sifatnya, (7) penilaian tingkat diperlukannya elaborasi kategori dan sifat-sifatnya, (8) klarifikasi konsep yang dikembangkan, dan (9) menggambarkan dan menjelaskan alasan analitis dari proses penelitian

Langkah 1-3 merupakan kegiatan pengkodean awal, pengkodean aplikasi, dan pengkodean perbandingan serta revisi. Pada langkah ini membagi data yang paling sering muncul dari hasil catatan observasi, dokumen yang diperoleh, dan transkrip wawancara. Pengkodean dilakukan sebagai kegiatan analisis awal untuk membangun kategori. Pengkodean melibatkan tiga subkomponen, yaitu penamaan, membandingkan, dan memoing terhadap data yang diperoleh untuk membangun kategori. Langkah 4-9 merupakan proses memeriksa kategori, membentuk, menerapkan, memodifikasi, serta mengelaborasi kategori, penjernihan konsep-konsep, dan menjelaskan proses penelitian.

\section{HASIL PENELITIAN DAN PEMBAHASAN}

Hasil penelitian ini menemukan bahwa nilai-nilai karakter yang diinternalisasikan di SMP 2 Bantul mengacu pada nilai-nilai utama yang dikemukakan oleh Kemendiknas sebagai berikut.

\section{Nilai Karakter dalam Hubungannya dengan Tuhan, meliputi Nilai Religius atau IMTAQ}

Nilai imtaq merupakan nilai utama yang dikembangkan di SMP 2 Bantul karena SMP 2 Bantul merupakan sekolah Pendais Model sehingga kegiatan sekolah mengacu pada program-program religius seperti sholat dhuha, sholat berjamaah, tadarus Al-Quran, pengajian, wisata rohani, dan manasik haji. Nilai imtaq ini sangat penting untu diinternalisasikan karena nilai ini berkaitan dengan keimanan seseorang. Orang yang beriman dan bertaqwa akan senantiasa menjalankan semua perintah Tuhan dan menjauhi semua larangan Tuhan karena orang yang beriman dan bertaqwa mempunyai keyakinan kuat dalam dirinya bahwa setiap perbuatan passti akan ada balasannya. Perbuatan baik akan mendapatkan pahala dan perbuatan tidak baik akan mendapatkan dosa.

\section{Nilai Karakter dalam Hubungannya dengan Diri Sendiri yang meliputi Nilai Jujur, Bertanggung jawab, Motivasi Berprestasi, dan Disiplin}

Nilai-nilai tersebut merupakan nilai utama yang selalu ditekankan oleh guru untuk dilaksanakan oleh siswa. Nilai kejujuran dianggap sebagai nilai yang sangat urgen untuk diinternali-sasikan karena kejujuran merupakan pangkal kebaikan. Orang yang jujur akan mampu mengendalikan sifat-sifat yang kurang baik seperti khianat, suka berbohong, suka menipu, dan suka menyontek.

Nilai tanggung jawab juga nilai penting untuk diinternalisasikan karena tanggung jawab berkaitan erat dengan pelaksanaan tugas dan kewajiban sehingga orang yang bertanggung jawab akan melaksanakan semua tugas dan kewajibannya dengan baik dan berani menanggung resiko sebagai konsekuensi dari tanggung jawabnya.

Motivasi berprestasi juga merupakan nilai yang diinternalisasikan di SMP 2 Bantul karena motivasi berprestasi juga merupakan daya penggerak untuk mencapai prestasi belajar setinggi mungkin. Orang yang memiliki motivasi berprestasi akan sanggup melakukan kerja keras dan berusaha semaksimal mungkin untuk meraih prestasi setinggi mungkin.

Nilai disiplin juga diinternalisasikan oleh guru karena nilai disiplin merupakan 
kunci sukses seseorang jika ingin berhasil, artinya kedisiplinan faktor utama yang akan menentukan keberhasilan seseorang karena kediplinan terkait dengan management waktu dan managemen diri. Sikap disiplin itu sangat dibutuhkan oleh seorang pelajar, karena sikap disiplin memiliki beberapa manfaat, antara lain: tidak menganggap remeh suatu pekerjaan, menumbuhkan sikap menghargai waktu, mempunyai sikap tanggung jawab yang besar, dan menumbuhkan kepatuhan pada peraturan.

\section{Nilai Karakter dalam Hubungannya dengan Sesama yang Ditanamkan di SMP 2 Bantul antara lain Sopan Santun, Kerja Sama, dan saling Menghargai}

Nilai sopan santun dipilih untuk ditanamkan pada siswa karena sopan santun sangat penting dalam kehidupan. Sopan santun merupakan cara yang paling mudah agar bisa diterima di masyarakat dan lingkungan karena sopan santun bersumber dari aturan yang ada dalam suatu masyarakat. Dengan menerapkan nilai sopan santun maka diharapkan peserta didik akan diterima di masyarakat.

Kerja sama merupakan nilai penting yang ditanamkan karena kerja sama berkaitan erat dengan kodrat manusia sebagai makhluk sosial yang tidak bisa hidup sendiri dan memerlukan orang lain. Oleh karena itu peserta didik secara dini dilatih untuk bekerja sama dengan orang lain. Dalam kerja sama ini terkandung nilai-nilai karakter yang lain seperti nilai saling menghargai, nilai tanggung jawab, nilai kesantunan, dan nilai disiplin.

Nilai saling menghargai juga merupakan nilai karakter dalam hubungan dengan sesama yang ditanamkan pada peserta didik di SMP 2 Bantul. Nilai saling menghargai juga merupakan nilai yang penting dalam membangun interaksi, karena dalam sebuah interaksi diperlukan sikap saling menghargai sehingga interaksi dapat berjalan harmonis dalam suasana yang kondusif. Saling menghargai ini sangat diperlukan dalam pergaulan masyarakat yang majemuk, terdiri dari berbagai suku, beragam agama, beragam budaya dan beragam latar belakang pendidikan. Penanaman nilai saling menghargai pada diri siswa bertujuan untuk membentuk pribadi siswa yang peka dan peduli terhadap orang lain, dapat menghargai perbedaan dan selalu bermusyawarah untuk mengambil keputusan.

\section{Nilai Karakter dalam Hubungannya dengan Lingkungan, yaitu Mencintai Lingkungan}

Mencintai lingkungan merupakan nilai yang sangat penting untuk ditanamkan pada peserta didik karena cinta lingkungan akan menumbuhkan sikap yang peduli pada kelestarian lingkungan hidup. Lingkungan hidup yang terjaga kelestariannya akan memberikan kehidupan yang layak bagi manusia, sedangkan lingkungan yang tidak terjaga kelestariannya akan menjadi sumber bencana bagi manusia.

\section{Nilai Kebangsaan, yang Meliputi Nasionalis atau Cinta Tanah Air dan Patriotisme atau Cinta Bangsa}

Cinta tanah air dan bangsa sangat penting ditanamkan agar peserta didik memiliki rasa nasionalisme dan patriotisme pada negara dan bangsa Indonesia. Cinta tanah air dan bangsa merupakan perasaan bangga menjadi warga negara Indonesia, dengan khasanah budaya yang ada dan menerima segala konsekuennya, yakni menjadi warga negara yang baik, patuh terhadap peraturan berupa norma maupun hukum yang tertulis serta ikut serta dalam usaha pembelaan terhadap negara Indonesia.

Cinta tanah air dan bangsa akan menimbulkan sikap nasionalisme dan patriotisme yaitu sikap-sikap yang ada dalam diri pejuang yang karena memiliki rasa cinta tanah air dan bangsa yang sangat besar, sehingga mereka rela berkorban demi negara ini. Dengan cinta tanah air dan bangsa maka harapannya generasi penerus yang akan menjalankan roda pemerintahan tanpa berdasarkan nafsu pribadi tetapi didasari semata-mata oleh rasa ingin memajukan bangsa dan negara Indonesia.

Nilai-nilai karakter tersebut kemudian diinternalisasikan pada peserta didik dengan pendekatan komprehensif yang meliputi dua metode tradisional, yaitu inkulkasi (penanaman) nilai dan pemberian teladan serta dua metode kontemporer, yaitu fasilitasi nilai dan pengembangan keterampilan hidup (soft skills). Metode fasilitasi berupa pemberian kesempatan kepada subjek didik dalam kegiatan pembelajaran maupun kegiatan pengembangan diri sehingga membawa dampak positif 
pada perkembangan kepribadian peserta didik.

Pengembangan keterampilan hidup (soft skills) berupa keterampilan akademik seperti berpikir kritis, berpikir kreatif dan berpikir analitis untuk menyelesaikan masalah, serta keterampilan sosial, yaitu keterampilan yang dimiliki seseorang untuk dapat berinteraksi dan berkomunikasi dengan orang lain, seperti keterampilan dalam bekerja sama, keterampilan dalam menyesuaikan diri, keterampilan dalam mengendalikan diri, keterampilan berempati, keterampilan menghargai orang lain, keterampilan mentaati peraturan, dan keterampilan berinteraksi.

Pendekatan komprehensif tersebut dilakukan melalui dua cara yaitu:

1. Kultur Sekolah

Pendidikan pada dasarnya memiliki tiga hal yang akan ditransfer melalui pendidikan, yaitu nilai (values), pengetahuan (knowledge), dan keterampilan (skills). Transfer nilai dilakukan melalui proses penanaman nilai dan keteladanan pendidik/tenaga pendidik dan seluruh stakeholder sekolah.

a. Pembiasaan

Pembiasaan dilakukan melalui peogram kegiatan dan program pembelajaran. Program kegiatan berupa salaman pagi, sholat dhuha, pengajian bersama, piket kebersihan kelas, tadarus Al-Quran, sholat berjamaah, gerakan $3 \mathrm{~S}$ (senyum, salam, sapa) dan lain-lain. Sedangkan pembiasaan melalui program pembelajaran dilakukan oleh guru ketika mengajar, seperti pembiasaan jujur dengan cara $\mathrm{m}$ elarang peserta didik untuk mencontek, pembiasaan disiplin dengan cara membiasakan siswa untuk tepat waktu masuk kelas, dan pembiasaan kerja sama dilakukan dengan cara membentuk kelompok dalam pembelajaran. Pembiasaan ini merupakan salah satu upaya untuk penanaman nilai atau inkulkasi nilai.

b. Keteladanan

Kepala sekolah membina keteladanan sikap guru, guru yang memiliki perilaku yang tidak dapat menunjukkan keteladanan akan dibina oleh kepala sekolah melalui pembinaan khusus, bahkan guru yang memiliki perilaku amoral dipindahkan dari sekolah.

2. Kegiatan pembelajaran dengan pendekatan kontekstual

Sebagian besar guru telah menggunakan pendekatan kontekstual dalam pembelajaran, yaitu pendekatan yang menuju pada proses pembelajaran yang bermakna. Proses pembelajaran yang bermakna merupakan proses pembelajaran yang mengaktifkan peserta didik dan memberi kesempatan peserta didik untuk mengembangkan kemampuannya. Adapun metode yang digunakan oleh guru bervareasi seperti Cooperative learning, Diskusi, Observasi, Contextual teaching and learning dan problem based learning.

Melalui pendekatan komprehensif tersebut sekolah menanamkan nilai-nilai karakter pada peserta didik agar peserta didik menginternalisasikan nilai-nilai tersebut. Internalisasi nilai dalam diri siswa melalui beberapa proses atau tahapan, antara lain:

1. Proses penerimaan nilai

Nilai diterima oleh seseorang dengan berbagai cara, antara lain dengan mendengarkan, melihat, dan membaca buku. Melalui indera pendengar dan penglihat siswa memperoleh pengetahuan tentang nilai, kebaikan, keburukan, dan manfaatnya bagi kehidupan.

2. Proses merespon nilai

Proses merespon dilakukan setelah seseorang mendapatkan pengetahuan nilai. Respon berarti balasan atau tanggapan (reaction), reaksi terhadap rangsang yang di terima oleh panca indra. Hal yang menunjang dan melatarbelakangi ukuran sebuah respon adalah sikap, persepsi, dan partisipasi. Berdasarkan pengetahuan nilai yang telah diterima, seseorang kemudian memberikan respon pada nilai yang telah diterima. Respon setiap orang berbeda-beda tergantung pada sikap, persepsi, dan partisipasi masing-masing individu.

Pada dasarnya ada tiga respon yang diberikan seseorang terhadap pengetahuan nilai yang telah diterima, yaitu:

a. Menerima nilai

Respon berupa menerima nilai ini terjadi bila nilai-nilai yang 
diterima dianggap sejalan dengan pemikiran peserta didik dan diyakini kebenaran serta kebermanfaatannya

b. Menolak nilai

Respon berupa menolak nilai ini terjadi bila peserta didik memiliki persepsi yang berbeda dengan nilai-nilai yang telah dia peroleh. Penolakan terhadap nilai-nilai ini pada dasarnya disebabkan oleh anggapan negatif terhadap sebuah nilai, misalnya nilai tertentu dianggap tidak sesuai dengan perkembangan jaman, dan nilai tertentu sulit untuk dilaksanakan. Sebagai contoh nilai kesusilaan yang mengajarkan pergaulan antara wanita dan pria terbatas, dianggap tidak sesuai dengan jaman lagi, sehingga nilai tersebut ditolak oleh peserta didik yang memiliki persepsi yang berbeda.

c. Acuh tak acuh

Respon berupa acuh tak acuh mengandung makna tidak peduli. Respon acuh tak acuh menggambarkan ketidakpedulian peserta didik terhadap nilai yang telah diterima, mengabaikan terhadap nilai yang telah diterima. Hal ini mengandung makna bahwa seseorang hanya mendengarkan dan mengetahui tentang nilai tertentu tetapi tidak memberikan respon terhadap pengetahuan nilai tersebut.

3. Proses seleksi nilai

Proses ini berlangsung setelah seseorang atau peserta didik telah menerima beberapa nilai dalam dirinya. Beberapa nilai yang telah peserta didik terima akan diseleksi dalam diri peserta didik. Proses seleksi ini pada dasarnya dilakukan berdasarkan tingkat kepentingan dan tingkat "kesenangan" terhadap nilai. Nilai-nilai yang "disenangi" atau nilai yang dianggap paling "penting" akan diterima terlebih dahulu kemudian secara bertahap nilai-nilai tersebut akan dihayati dalam dirinya.

4. Proses internalisasi atau penghayatan nilai (mempribadikan nilai)

Proses menghayati nilai mengandung makna mengalami dan merasakan nilai-nilai tersebut dalam batinnya. Menghayati atau mempribadikan nilai juga mengandung arti merasakan betul-betul tentang nilai-nilai yang telah diterima sampai dalam hati sanubari sehingga menumbuhkan kesadaran dalam dirinya untuk melakukan nilai tersebut. Nilainilai tersebut sedikit demi sedikit akan merasuk dalam sanubarinya dan akan menjadi bagian dari kepribadiannya. Kesadaran akan pentingnya nilai tersebut bagi kehidupannya tumbuh setelah ia menghayati nilai-nilai tersebut dan meyakini kebenaran dan kebermanfaatan nilainilai tersebut.

5. Proses aktualisasi atau penerapan nilai

Penerapan nilai merupakan tahapan akhir dalam proses internalisasi nilai. Penerapan ini akan terjadi setelah melalui proses penghayatan nilai. Seseorang yang telah menghayati nilai maka akan mendorong dirinya untuk mengaktualisasikan nilai tersebut dalam perilakunya. Orang tersebut telah memiliki kesadaran pada dirinya sendiri untuk menerapkan nilainilai tersebut dalam kehidupannya.

Melalui proses internalisasi tersebut, nilai-nilai karakter yang berasal dari luar masuk dan mendarah daging dalam diri peserta didik. Nilai-nilai yang telah terinternalisasi dalam diri peserta didik tersebut kemudian teraktualisasi dalam perilaku seharihari, dalam arti dihayati dan diamalkan. Beberapa nilai karakter yang telah diaktualisasikan antara lain: nilai religius, kejujuran, tanggung jawab , kesopanan, saling menghargai, dan peduli pada lingkungan. Jika ditinjau berdasarkan kerangka pikir maka ada satu nilai yang belum diaktualisasikan yaitu nilai cinta tanah air dan bangsa. Berdasarkan hasil wawancara dengan beberapa siswa dapat disimpulkan bahwa tidak teraktualisasikannya nilai cinta tanah air karena kekecewaan para siswa terhadap para pejabat pemimpin bangsa yang menunjukkan perilaku amoral seperti kasus korupsi, gratifikasi, pencucian uang dan tindakan lainnya yang tidak dapat dijadikan sebagai teladan. Kekecewaan tersebut telah melunturkan rasa bangga terhadap negaranya, dan mengikis rasa cinta terhadap negara dan bangsanya.

\section{Konsep Internalisasi Nilai}

Berdasarkan analisis hasil wawancara dan didukung oleh kajian teori yang ada maka konsep internalisasi nilai-nilai karakter 
pada dasarnya adalah proses merasuknya nilai karakter ke dalam diri seseorang sehingga nilai-nilai tersebut mendarah daging dalam dirinya, menjiwai pola pikir, sikap, dan perilakunya serta membangun kesadaran diri untuk mengaplikasikan nilai-nilai tersebut.

Berdasarkan makna di atas, terdapat empat indikator yang terkandung dalam makna internalisasi, yaitu:

a. Internalisasi merupakan sebuah proses Internalisasi merupakan suatu proses karena di dalamnya ada unsur perubahan dan waktu. Proses penanaman nilai memerlukan waktu yang terus menerus dan berkelanjutan sehingga seseorang akan menerima nilai-nilai yang telah ditanamkan pada dirinya dan akan memunculkan perilaku sesuai dengan nilai yang diperolehnya. Hal ini berarti ada perubahan dalam diri seseorang itu dari belum memiliki nilai tersebut menjadi memiliki, atau dari sudah memiliki nilai tersebut tetapi masih lemah dalam mempengaruhi perilakunya menjadi memiliki nilai tersebut lebih kuat mempengaruhi perilakunya.

Berdasarkan proses tersebut maka ada dua hal yang menjadi inti internalisasi, yaitu: (1) proses penanaman atau pemasukan sesuatu yang baru dari luar ke dalam diri seseorang, dan (2) proses penguatan sesuatu yang telah ada dalam diri seseorang sehingga membangun kesadaran dalam dirinya bahwa sesuatu tersebut sangat berharga.

b. Mendarah daging

Mendarah daging mempunyai makna bahwa sesuatu telah meresap dalam sanubarinya sehingga menjadi kebiasaan yang tidak bisa dilepaskan dari dirinya. Sebagai contoh dalam diri seseorang telah mendarah daging melakukan sholat Dhuha, maka orang tersebut akan melakukan sholat dhuha dengan sendirinya, tanpa perlu diingatkan, atau tanpa memerlukan pemaksaan dari orang lain, karena sholat dhuha sudah menjadi kebiasaan dalam dirinya. Jika dia tidak melakukan sholat dhuha maka dia akan merasakan ada sesuatu yang hilang dalam dirinya.

c. Menjiwai pola pikir, sikap, dan perilaku Makna menjiwai dalam internalisasi adalah bahwa nilai-nilai karakter menjadi dasar dalam pola pikir, sikap, dan perilaku. Nilai-nilai karakter yang telah tertanam dalam diri seseorang akan membangun pola pikir (mindset) dalam diri seseorang selanjutnya nilai tersebut akan menjadi dasar dalam bersikap dan berperilaku. Sebagai contoh seseorang telah berhasil menginternalisasi nilai kejujuran dalam dirinya sehingga menjiwai pola pikir, sikap, dan perilakunyan, maka dalam mindset seseorang akan terbangun pikiran bagaimana melakukan sesuatu secara jujur, tidak ada penipuan, kelicikan dan kecurangan, ada rasa takut untuk berbuat tidak jujur, karena dia telah memahami bagaimana manfaat jujur dan apa akibatnya bila dia tidak berbuat jujur. Karena kejujuran telah mendasari mindsetnya maka kejujuran tersebut dengan sendirinya akan mendasari sikap dan perilakunya. Pikiran yang jujur akan diterjemahkan dalam sikap yang jujur dan perilaku yang jujur pula.

d. Membangun kesadaran diri untuk mengaplikasikan

Kesadaran diri merupakan komponen kecerdasan emosional yang mengandung arti mempunyai pemahaman terhadap sesuatu dalam hal ini nilai yang menjadi sumber kekuatan dan pendorong diri untuk mengaplikasikan nilai-nilai tersebut. Kesadaran diri merupakan pemahaman seseorang akan nilai-nilai dan tujuan diri. Seseorang yang sadar diri tahu kemana arah yang akan ia tuju dan mengapa ia melakukannya. Keputusan yang diambil oleh orang dengan kesadaran diri tinggi akan cenderung selaras dengan nilai-nilai yang mereka anut sehingga membuat mereka berperilaku sesuai nilai-nilai yang dianutnya.

Dengan internalisasi nilai akan terbangun kesadaran diri sehingga seseorang mengaplikasikan nilai-nilai yang telah diinternalisasikannya selaras dengan hatinya, ada ketulusan dalam mengaplikasikan nilai, tanpa ada kepurapuraan karena tujuan tertentu. Sebagai contoh orang yang telah berhasil menginternalisasi nilai sopan santun, maka orang tersebut secara tulus akan bersikap sopan pada orang lain, bukan karena mempunyai tujuan untuk mendapatkan pujian, penghargaan, dan lain-lain. 
Kesadaran diri ini akan membangun kebiasaan dalam diri seseorang untuk melakukan nilai-nilai yang telah berhasil diinternalisasikan.

Kebiasaan adalah pengulangan sesuatu secara terus-menerus atau dalam sebagian besar waktu dengan cara yang sama dan tanpa melalui proses berpikir atau sesuatu yang tertanam di dalam jiwa dari hal-hal yang berulang kali terjadi dan diterima sebagai tabiat dirinya. Berdasarkan makna kebiasaan tersebut, maka kesadaran diri untuk mengaplikasikan nilai karakter merupakan penerapan nilai-nilai karakter dalam perilaku seharihari secara berulang-ulang tanpa melalui proses berpikir, karena di dalam dirinya telah tertanam kebutuhan dan keharusan untuk menerapkan nilai-nilai karakter tersebut sehingga nilai-nilai karakter tersebut telah menjadi tabiatnya atau menjadi bagian dari dirinya, dan menjadi salah satu karakteristik dirinya sebagai individu.

Berdasarkan uraian di atas maka konsep internalisasi dapat divisualisasikan seperti Gambar 2.

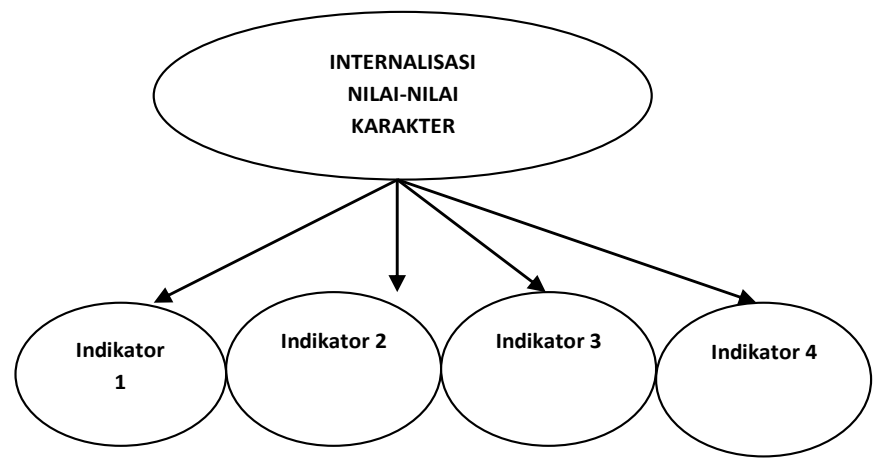

Gambar 2. Konsep dan Indikator Internalisasi Nilai-Nilai Karakter

Keterangan Gambar:

Indikator 1 : Internalisasi merupakan sebuah proses

Indikator 2 : Mendarah daging

Indikator 3 : Menjiwai pola pikir, sikap, dan perilaku

Indikator 4 : Membangun kesadaran diri untuk mengaplikasikan

\section{Konsep Aktualisasi Nilai-Nilai}

Berdasarkan analisis hasil wawancara tentang makna internalisasi dan didukung oleh kajian teori yang ada maka penelitian ini menemukan konsep tentang aktualisasi nilainilai karakter. Aktualisasi nilai-nilai karakter adalah proses lanjut dari internalisasi berupa tahapan penerapan atau pengamalan nilai-nilai karakter dalam perilaku sehari-hari atas dasar kesadaran, dan perilaku tersebut menjadi bagian dari kepribadiannya.

Berdasarkan konsep tersebut, terdapat empat indikator yang terkandung pada konsep aktualisasi nilai-nilai karakter, yaitu:

a. Merupakan proses lanjut dari internalisasi

Aktualisasi merupakan proses lanjut dari internalisasi, hal ini mengandung dua makna, yaitu:
1) Aktualisasi merupakan kelanjutan dari internalisasi, artinya aktualisasi baru terjadi setelah seseorang berhasil menginternalisasikan nilai-nilai karakter pada dirinya.

Jadi aktualisasi harus diawali dengan proses internalisasi. Apabila seseorang tidak mampu menginternalisasikan nilai-nilai karakter pada dirinya maka dia juga tidak akan mampu mengaktualisasikan nilai-nilai karakter atas dasar kesadaran diri.

2) Aktualisasi nilai-nilai karakter memerlukan proses dan tahapan khusus. Nilainilai tidak bisa ditransfer hanya dengan diajarkan dan diujikan, seperti mengajarkan keterampilan atau pengetahuan. Namun nilai-nilai memerlukan proses internalisasi, baru kemudian nilai-nilai 
tersebut dapat teraktualisasi dalam perilaku siswa.

b. Pengamalan nilai-nilai karakter

Inti dari aktualisasi nilai-nilai adalah penerapan atau pengamalan nilai-nilai tersebut dalam perilakunya. Nilai-nilai yang telah berhasil diinternalisasikan kemudian diterapkan dalam kehidupan sehari-hari. Sebagai contoh orang yang mengaktualisasikan nilai tanggung jawab, maka perilakunya menunjukkan perilaku yang bertanggung jawab seperti apabila diberi amanah dilaksanakan, apabila diberi tugas dilaksanakan, dan berani menanggung resiko terhadap apa yang telah dilakukannya.

c. Bagian dari kepribadian seseorang yang mengaktualisasikan nilai.

Kepribadian merupakan keseluruh sikap, perasaan, ekspresi, temparmen, ciri-ciri khas dan perilaku seseorang Sikap perasaan ekspresi dan tempramen itu akan terwujud dalam tindakan seseorang jika di hadapkan pada situasi tertentu. Setiap orang mempunyai kecenderungan perilaku yang baku, atau berlaku terus menerus secara konsisten dalam menghadapai situasi yang di hadapi, sehingga menjadi ciri khas pribadinya. Orang yang mengaktualisasikan nilai jujur, maka kejujuran tersebut menjadi bagian dari kepribadiannya. Wujud konkritnya adalah dimanapun kapanpun, dalam situasi apapun orang tersebut akan berperilaku jujur, karena jujur telah menjadi bagian dari pribadinya.

Berdasarkan uraian di atas maka aktualisasi nilai karakter dapat divisualisasikan seperti gambar 3 .

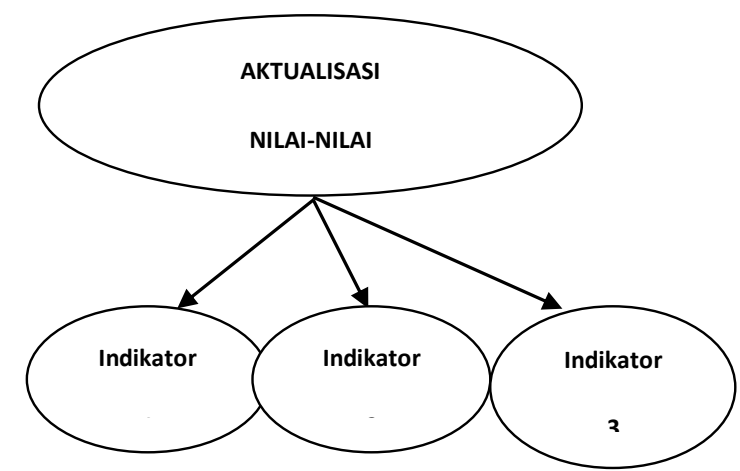

Gambar 3. Konsep dan Indikator Aktualisasi Nilai-Nilai Karakter

Keterangan gambar:

Indikator 1 : Merupakan proses lanjut dari internalisasi

Indikator 2 : Penerapan atau pengamalan nilai-nilai karakter

Indikator 3: Bagian dari kepribadian seseorang yang mengaktualisasikan nilai-nilai karakter

\section{Formulasi Hipotesis}

Berdasarkan konseptualisasi yang telah diuraikan di atas, maka dapat disusun sebuah hipotesis, yaitu terdapat hubungan antara internalisasi dan aktualisasi nilai-nilai karakter. Bahwa aktualisasi nilai-nilai karakter merupakan kelanjutan dari internalisasi nilai-nilai karakter. Artinya aktualisasi merupakan pengamalan dari hasil internalisasi (penghayatan) nilai-nilai karakter. Aktualisasi nilai-nilai karakter akan berhasil apabila didukung oleh lingkungan yang kondusif. Sebagai contoh SMP 2 Bantul menginternalisasikan nilai cinta tanah air, namun nilai tersebut tidak teraktualisasi dalam perilaku siswa karena siswa merasa kecewa dengan banyaknya kasus pejabat yang korup.

Untuk menguji hipotesis ini diperlukan penelitian lanjutan multi kasus. Apabila hasil penelitian lanjutan masih ada kasus negatif dalam arti menolak hipotesis ini maka hipotesis perlu diformulasikan kembali dengan melengkapi rumusan. Setelah tidak ada kasus yang bersifat negatif, dapat disimpulkan bahwa hipotesis tersebut berlaku umum maka dihasilkan sebuah teori sebagai tahap akhir grounded theory.

\section{SIMPULAN}

\section{Simpulan}


Berdasarkan hasil penelitian, dapat ditarik simpulan bahwa nilai-nilai karakter yang diupayakan oleh sekolah untuk diinternalisasikan dalam diri siswa SMP 2 Bantul adalah nilai religius, kejujuran, tanggung jawab, kesopanan, saling menghargai, peduli pada lingkungan, cinta tanah air dan bangsa. Nilai-nilai tersebut dipilih untuk diinternalisasikan dengan dasar pertimbangan bahwa nilainilai tersebut merupakan nilai-nilai yang mendasari nilai-nilai karakter lainnya. Sebagai contoh nilai peduli pada lingkungan, di dalamnya juga terkandung nilai cinta pada lingkungan baik lingkungan sosial maupun lingkungan hidup, saling menghargai, menjaga amanah, hemat, berpikir kreatif untuk mencari energi alternatif, bertanggung jawab, disiplin, dan bergaya hidup sehat.

Proses internalisasi nilai-nilai karakter pada diri siswa SMP 2 Bantul dilakukan melalui lima tahapan. Pertama, proses penerimaan nilai, yang dilakukan dengan cara mendengarkan ceramah guru untuk mendapatkan pengetahuan nilai, melihat orang melakukan nilai-nilai karakter tertentu yaitu dengan melihat contoh perilaku orang lain, dan membaca buku. Kedua, proses merespon nilai, yang meliputi proses menerima nilai, menolak nilai, dan acuh tak acuh. Apabila respon siswa pada menolak nilai dan acuh tak acuh maka proses internalisasi akan berhenti di sini, namun apabila siswa merespon dengan menerima nilai maka proses akan berlanjut pada tahapan berikutnya. Ketiga, proses seleksi nilai, berupa proses pemilahan nilai yang mendapat respon diterima. Pemilahan atau seleksi nilai berdasarkan tingkat kesenangan atau kepentingan nilai. Nilai-nilai yang disenangi atau dianggap penting akan mendapat prioritas utama untuk ditindaklanjuti dalam tahapan berikutnya. Keempat, proses penghayatan nilai atau mempribadikan nilai, yaitu merasakan betul-betul tentang nilai yang telah diterima sampai dalam hati sanubari sehingga menumbuhkan kesadaran dalam dirinya untuk melakukan nilai-nilai tersebut, dan kelima, proses penerapan nilai atau aktualisasi nilai, yaitu penerapan nilai-nilai karakter dalam perilaku sehari-hari dengan penuh kesadaran tanpa adanya paksaan dari pihak lain.

Berdasarkan proses internalisasi nilainilai karakter yang telah dilakukan oleh siswa, terdapat beberapa nilai karakter yang berhasil diaktualisasikan dalam perilaku sehari-hari siswa di SMP 2 Bantul. Adapun nilai-nilai tersebut adalah nilai religius, kejujuran, tanggung jawab, kesopanan, saling menghargai, dan peduli pada lingkungan. Terdapat satu nilai yang belum berhasil diaktualisasikan dalam perilaku siswa yaitu nilai cinta tanah air dan bangsa. Nilai tersebut tidak berhasil diaktualisasikan karena kondisi lingkungan yang tidak mendukung terhadap proses internalisasi dan aktualisasi nilai-nilai karakter. Kondisi lingkungan yang tidak mendukung tersebut digambarkan dengan banyaknya kasus penyimpangan sosial yang dilakukan oleh para pemimpin dan wakil rakyat seperti kasus korupsi, gratifikasi, pelecehan, dan berbagai tindak kekerasan.

\section{Implikasi}

Penelitian yang dilakukan ini menghasilkan beberapa temuan penting khususnya yang berhubungan dengan inter-nalisasi nilainilai karakter. Hasil penelitian ini mengungkapkan bahwa internalisasi nilai-nilai karakter dapat dilakukan dengan pende-katan komprehensif melalui integrasi dalam kultur sekolah dan pembelajaran. Pendekatan komprehensif dalam kultur sekolah dilakukan melalui pembiasaan dan keteladanan, sedangkan integrasi dalam pembelajaran dilakukan dengan pendekatan kontekstual. Pendekatan komprehensif tersebut ternyata berhasil diterapkan dalam menginternalisasikan nilai-nilai karakter pada diri siswa sehingga siswa mengaktualisasikan nilai-nilai tersebut dalam perilakunya sehari-hari.

Temuan penelitian ini dapat menjadi bahan pertimbangan bagi kepala sekolah untuk menginternalisasikan nilai-nilai karakter melalui pendekatan komprehensif. Pendekatan komprehensif merupakan pendekatan yang menerapkan metode tradisional dan kontemporer. Metode tradisional berupa penanaman nilai dan keteladanan, sedangkan metode kontemporer berupa fasilitasi nilai dan pengembangan keterampilan hidup (soft skills). Metode fasilitasi berupa pemberian kesempatan ke-pada subjek didik dalam kegiatan pembelajaran maupun kegiatan pengembangan diri sehingga membawa dampak positif pada perkebangan kepribadian peserta didik. Pengembangan keterampilan hidup (soft skills) berupa keterampilan akademik seperti berpikir kritis, berpikir kreatif dan berpikir analitis 
untuk menyelesaikan masalah, serta keterampilan sosial, yaitu keterampilan yang dimiliki seseorang untuk dapat berinteraksi dan berkomunikasi dengan orang lain, seperti keterampilan dalam bekerja sama, keterampilan dalam menyesuaikan diri, keterampilan dalam mengendalikan diri, keterampilan berempati, keterampilan menghargai orang lain, keterampilan mentaati peraturan, dan keterampilan berinteraksi.

Internalisasi nilai-nilai karakter dapat dimulai dengan mengidentifikasikan nilainilai yang akan diinternalisasikan, kemudian menentukan pendekatan yang akan digunakan untuk menginternalisasikan nilai-nilai tersebut pada diri siswa, selanjutnya menyusun perencanaan program jangka pendek, menengah dan panjang untuk menginternalisasi dan mengaktualisasi nilai-nilai tersebut. Berdasarkan program tersebut kemudian disusun rencana aksi untuk melaksanakan program-program yang telah disusun. Setelah programprogran tersebut dilaksanakan kemudian dilakukan monitoring dan evaluasi untuk mengetahui ketercapaian program. Hasil evaluasi digunakan untuk tindak lanjut. Demikian tahapan-tahapan tersebut diulang secara terusmenerus sehingga tercapai indikator keberhasilan yang telah ditetapkan.

\section{Saran}

Berdasarkan pembahasan hasil penelitian, kesimpulan penelitian dan implikasi penelitian yang telah disampaikan di atas maka dalam rangka internalisasi nilai-nilai karakter pada siswa diajukan saran-saran sebagai berikut: (1) nilai-nilai karakter yang telah berhasil diaktualisasikan siswa sebaiknya tetap dipertahankan keberadaannya dengan cara tetap melakukan pembiasaan dan keteladanan sehingga nilai-nilai tersebut tidak luntur atau hilang, (2) nilai-nilai yang belum berhasil diaktualisasikan perlu ditindaklanjuti dengan memberi perlakuan khusus dan dimonitoring secara terus menerus. Untuk pelaksanaan tindakan tersebut sekolah dapat membentuk tim khusus yang bertugas merumuskan tindakan dan memantau tindakan yang dilakukan. Tim dapat dibentuk dengan melibatkan seluruh stakeholder sekolah seperti Komite Sekolah, kepala sekolah, guru dan TU, dan (3) penelitian ini perlu ditinjak lanjuti dengan penelitian multi kasus untuk menguji hipotesis yang telah ditemukan dalam penelitian ini sehinga pada akhirnya apabila temuan penelitian berikutnya bersifat positif maka akan dihasilkan teori baru.

\section{DAFTAR PUSTAKA}

Egan, T.M. (2009). Grounded Theory Research and Theory Building. Advance in developing Human Resources. Vol 4 No 3 August 2002.

Kemendiknas. (2010). Pembinaan pendidikan karakter di Sekolah Menengah Pertama. Jakarta: Kemendiknas

Kirschenbaum, H. (1995). 100 ways to enhance value and morality in schools and youth setting. Boston: Allyn and Bacon

Muhadjir, N (2000) Ilmu pendidikan dan perubahan sosial: Teori pendidikan pelaku sosial kreatif. Yogyakarta: Rake Sarasin

Pearson,Q.M \& Nicholson, J.I. (Juni 2000). Comprehensive character education in the elementary school. Journal of Humanistic Counseling, Education and Development; Jun 2000; 38, 4; ProQuest Education Journals pg. 243

Suwito, U., et al. (2008). Tinjauan berbagai aspek character building: Bagaimana mendidik anak berkarakter. Yogyakarta: Tiara Wacana

Zubaedi. (2012). Design pendidikan karakter: Konsepsi dan aplikasinya dalam lembaga pendidikan. Jakarta: Kencana Prenada Media Group. 